\title{
Equal Representation of Party Members on Political Party Central Committees
}

\author{
Shortly before the turn of the century, a Connecticut Democrat
} wrote impatiently that "we of New Haven are tired of the rotten borough system in the government of the state, and equally so of its offspring, the rotten borough system of the party. ... Give us a democratic party," he implored, "and we will give you a democratic state." 1 Were the partisan correspondent alive today, he would find that state laws have preserved the "rotten borough system of the party" by apportioning equal numbers of representatives on party central committees to unequal numbers of party members. ${ }^{2}$

State law allocates representation on party central committees in the majority of states." Typically, the state central committees of both major parties ${ }^{4}$ are composed of an equal number of committee mem-

1. Pardee, Duty of the Democrals, Letter to the Editor of New Haven Register, June 22, 1890, reprinted in W. PardeE, Equal Representation (1890). The tcrm "rotten borough" describes cighteenth-century English parliamentary districts that contained few or no constituents yet elected representatives to the House of Commons. See. generally $\mathrm{L}$. Namier, The Structure of Politics at the Accession of George III 62-157 (1963).

2. This Note considers apportionment of only the state and county central committees of the two major political parties in the United States, the Democratic Party and the Republican Party. These parties are organized on a statewide basis, with county units. F. Sorauf, P.IRTy Politics in America 114-15 (3d ed. 1976). Although the laws governing party organization in some states also establish and apportion central committees at intermediate levels of party organization, such as cities, towns, or congressional districts, e.g., IND. Code ANN. \$ 3-1-2-1 (Burns 1972); N.D. CeNT. Code \$ 16-17-09 (1971), state and county central committees administer the bulk of the parties' business. F. Soralf, supra, at 68.69. The standards set forth in this Note could be applied to statutory apportionment of intermediate level central committees when the activities of such committecs are integrally related to general elections. See pp. 173-75 infra.

Each major party maintains a national committee composed of committec members from cach state. Because party rules rather than state law have apportioned representation on national committecs, the state action needed to invoke the equal protection clause is lacking. See note 17 infra. At any rate, the partics' national committees are largely powerless in the face of the "autonomous power" of state and local party organizations, 1:. Sorivf, sufra, at 131, and thus are not as integrally related to the electoral process as arc state and county central committes. See pp. 173-74 infra. Se'e generally C. CoTTER \&: B. HFWessy, Politics Without Power (1964) (discussing national party committecs).

3. The methols of central committec apportionment prescribed by statute are summarized in notes 5 \& 6 infra.

4. Mrost states cither impose no gorcrnance structure on minor political parties, i.e., partics whose candidates received less than a specified percentage of the vote for a particular office in a preceling gencral election or require minor partics to devise their own forms of party gorernance. E.g., Omo REv. CovE ANs. \$3.17.03 (Page 1972). Although central committes of minor parties can perform essentially the same functions as central comnittes of major parties and thus act as integral parts of the state's clectoral process, see pp. 173-74 infra, the absence of state action that establishes and cnforces 
bers from each congressional district or county. ${ }^{5}$ County central committees generally consist of an equal number of committee members from each ward or precinct. $^{6}$ Yet there may be great variation in

apportionment of committee members on minor party central committees places apportionment of minor party central committees beyond the ambit of the equal protection clause, see note 17 infra. Hence, the argument of this Note does not apply to apportionment of minor party central committee members.

5. In 22 states, the law requires major political partics to establish state central committees composed of an equal number of committee members from each unit of repre. sentation. See Cal. Elec. Code \$§ 8660, 9160 (Supp. 1978); FlA. Stat. ANN. § 103.111 (Harrison 1975 \& Supp. 1977); IDAHO CoDE \$ 34-504 (Supp. 1977); IND. Code ANN. \$ 3-1-2-1 (Burns 1972); Iowa Code ANN. \$ 43.111 (West Supp. 1977); K.x. STAT. AxN. \$ 25-380t (Supp. 1976); Mass. ANx. Laws, ch. 52, \$ 1 (Law. Co-op. 1978); Mich. Comp. L.sws AxN. $\$ 168.597$ (West 1967); Miss. Code ANN. $\$ 23-1-3$ (Supp. 1977); Mo. Anv. STat. \$ 115.621 (Vernon Supp. 1978); Mont. Rev. Codes ANN. \$ 23-3403 (Supp. 1977); Nev. Rev. Stat. \$ 293.153 (1975); N.J. Stat. ANN. \$ 19:5-4 (West 1964); N.D. Cent. Code \$ 16-17-11 (1971); Ohio Rev. Code AnN. $\$ 3517.03$ (Page 1972); S.C. Code $\$ 7-9.90$ (1976); S.D. Comr. L.ws AnN. \$ 12-5-16 (1975); Tenn. Code AnN. \$2-1304 (Supp. 1977); Tex. Elec. Code AnN., tit. 13, $\$ 38$ (Vernon Supp. 1978); VT. Stat. ANN., tit. 17, § 730 (1968); Wash. Rev. Code ANx. \$ 29.42 .020 (Supp. 1976); W. VA. Code \$ 3-1-9 (Supp. 1978); Wyo. STAt. \$\$ 22-4-105, -110 (1977). Election laws in five states establish state party central committees in which the number of committee members from cach unit of representation bears a rough relationship to party membership. See ARIz. Rev. STAT. ANN. \$ 16-233 (West 1975); Colo. Rev. Stat. \$ 1-14-108(2) (Supp. 1976); LA. Rev. Stat. A.N. \$ 18:285(1) (West 1969 \& Supp. 1977); Ore. Rev. Stat. \$ 248.075 (1977); Utah Code ANN. \$ 20-4-2 (1976). Such laws may; however, apportion equal numbers of committee members to unequal numbers of party members by providing a minimum number of committee members from each unit of representation. Nevertheless, if no committee member represents $16.4 \%$ more or less party members than any other committee member, these apportionment statutes may satisfy constitutional standards. See note 53 infra.

The party organization law of Illinois provides for a mixed system of central committee representation in which equal numbers of committee members represent districts in which unequal numbers of party members live, yet committee members cast votes weighted to reflect the number of party members in each district. See Ilr. Ax.. Stat. ch. 46, $\$ 7-8(a)$ (Smith-Hurd Supp. 1978). Weighted roting, however, may not wholly eliminate the malapportionment problem. See pp. 183-84 infra.

6. State law in 21 states requires political partics to establish county central committees composed of an equal number of committce members from each unit of representation. See CAL. Elec. CodE $\$ \$ \$ 8820-8825,9320-9325$ (West 1977) (limited to certain counties); Colo. Rev. St.t. \$ 1-14-1081(1) (Supp. 1976); Fla. St.ıT. ANN. \$ 103.111 (Harrison 1975 \& Supp. 1977); IDAHo CODE \$ 34-502 (Supp. 1977); IND. CODE ANN. \$ 3-1-2-1 (Burns 1972); Kax Stat. A.N. \$ 25-3802 (1973); LA. Rev. Stat. ANN. \$ 18:285(9) (Supp. 1978); Mp. ANx. Code, art. 33, \$ $11-2$ (Supp. 1977); Mass. ANs. LAws, ch. 52, \$\$ 2-4, -9 (Law. Co-op. 1978); Mich. Comp. Laws ANs. \$ 168.599 (West 1967 \& Supp. 1978); Miss. Code ANs. \$ 23-1-3 (Supp. 1977); Mo. AN.s. Stit. \$ 115.607 (Vernon Supp. 1978); MoNT. Rev. Codes ANN. \$S 23-3401, -3402 (Supp. 1977); N.J. STAT. AN. \$ 19:5-3 (Supp. 1977); OHo Rev. Code ANN. \$ 3517.03 (Page 1972); S.C. Cone \$ 7.9.60 (1976); S.D. Comp. Laws A.N. $\$ \S 12-5-13,-14$ (1975 \& Supp. 1977); Tex. Elec. Code AxN., tit. 13, $\$ 18$ (Vernon Supp. 1978); Wastr. Rev. Code ANN. \$29.42.030 (Supp. 1976); W. VA. Code \$ 3.1.9 (Supp. 1978); Wis. STAT. ANx. \$ 8.17 (West 1967 \& Supp. 1977). The clection laws of ten states establish county central committees in which the number of committec members from cacl unit of representation is or may be based partially on party membership thercin. Sce ARIz. Rev. Stat. ANN. \$ 16-231 (West 1975); C.1L. Elec. Code $\$ \$ \$ 8820,9320$ (West 1977) (limited to certain countics); Iows Cove ANN. $\$ 43.99$ (West Supp. 1977); Nev. Rev. St.st. \$ 293.143 (1975); N.Y. Elec. L.W \$ 2-104 (McKinney 1977); N.D. CENT. Code \$S 16-17-2, -09 (1971 \& Supp. 1977); Ore. Rev. Stat. \$\$ 248.015, .025 (1977); LTan Cove Åx. \$ 20-4-i (197(i); Vt. Stat. A.N., tit. 17, \$727 (1968); Wro. Stat. \$ 22-1-101 (1977). lllinois and Cew 


\section{Representation on Party Committees}

party membership ${ }^{7}$ among the districts to which states ordinarily assign an equal number of comittee members. ${ }^{8}$

Malapportionment of central committee representation gives party members in districts that contain few party adherents a disproportionate opportunity to influence decisions made by the party central committee. ${ }^{0}$ The central committee selects the party chairman and other party committees and adopts party bylaws. ${ }^{10}$ Although party candidates formally are chosen at a primary election or convention, ${ }^{11}$ the central committee normally guides the party's choice by recruiting and endorsing a slate of candidates for party nomination. ${ }^{12}$ The central committee thereafter coordinates the party election drive. ${ }^{13}$ When a vacancy occurs on the party's general election ticket due to the death or disability of a regularly nominated candidate, the central committee in most states names a replacement. ${ }^{14}$ In addition, the central committee of the party in power generally controls the assignment

York apportion equal numbers of county central committee members to districts containing unequal numbers of party members yet provide for weighted roting by each committee member to reflect the number of party members he represents. See ILL. ANN. STat., cl. 46, § 7-8(c) (Smith-Hurd Supp. 1978); N.Y. Elec. LAw § 2-104 (McKinney 1977). Problems of unequal representation may persist, however, despite use of weighted voting. See pp. 183-84 infra.

7. See pp. 181-82 infra.

8. This wide rariation is reflected in the primary and general election returns collected in M. Barone, G. Ujifusa \& D. Mattheivs; The Almanac of American Politics 1978 (1977) (includes 1976 presidential and congressional election return data by congressional district); Congrcssional Quarterly, Guide to U.S. Elections 545.880 (1975) (records popular vote in all U.S. congressional elections); R. Scammon \& A. McGillivray, America Votes 12: A Handbook of Contemporary American Election Statistics (1976) (includes presidential, gubernatorial, senatorial, and congressional election returns by congressional district, county, and ward). The measure of party membership, of course, depends on local political circumstances. Election returns may not always provide an accurate index of a party's support for central committee representation purposes. In such cases, party registration figures may prove to be a more appropriate standard for measuring party membership. See pp. 181-82 infra.

9. For cxample, the Ohio party organization law, OHio Rev. Code ANN. \$3517.03 (Page 1972), apportions the same number of committee members to the 50,000 Democrats of the Tentl Congressional District in rural southeastern Ohio and to the 90,000 Democrats in the Youngstown-dominated Nineteenth Congressional District. See M. Barone, G. Ljiftsi \& D. Matrhews, supra note 8, at 669, 683 (party member figures based on votes cast for Democratic congressional candidate in the 1976 general election).

10. See, e.g., Ohio Rev. Code ANn. \$\$ 3517.03, o4 (Page 1972); Wash. Rev. Code ANN. SS 29.020, .030 (Supp. 1976); V.O. Key. Politics, Parties and Pressure Groups $325-28$ (5th ed. 1964); A. Rin.iey \& W. Kexdill, DeMocricy ANd the AMericin Party System 226-30 (1956).

11. For a revicw of the formal nominating procedures of political parties, see Developments in the Law-Elections, 88 HARv. L. REv. 1111, 1151-54 (1975).

12. See p. 175-77 infra; R. Huckshorn, Party Leadership in the States 105 (1976); F. Sorauf, supra note 2, at 222-27.

13. A. RANNEY \& W. KeNDAlL, supra note 10, at 226.

14. See, e.g., N.Y. Elec. Law \$ 6-116 (McKinney 1977); TEx. Elec. Code ANN., tit. 13, $\S 56$ (Vernon Supp. 1978). 
of government jobs to party loyalists..$^{15}$ Malapportionment of central committee representation therefore deprives party members of equal representation in the conduct of these important party affairs. ${ }^{16}$

This Note argues that party members have a constitutional right to equal central committee representation when state law apportions central committee members. ${ }^{17}$ The equal protection clause of the

15. A. RANney \& W. KeNdall, supra note 10, at 226-27; F. Sorauf, supra note 2, at 72-77. But cf. Elrod v. Burns, 427 U.S. 347 (1976) (patronage dismissal from government employment violates First and Fourteenth Amendments). See generally M. ToLchin \& $\mathbf{S}$. Tolchin, To THE Victor ....(1971).

16. General discussions of the role of central committees in the conduct of party affairs are available in V.O. KEY, supra note 10, at 314-28; G. RIGBY, STATE AND LOCAL Government and Politics 52.54 (1969); F. Sorauf, supra note 2, at 64-72; Ranncy, Parlies in State Politics, in Politics in the American States 92-93 (H. Jacob \& $\mathrm{K}$. Vines eds. 1971).

17. Because the equal protection clause applies only to state action, see, e.g., Moose Lodge No. 107 v. Irvis, 407 U.S. 163, 172 (1972) ("essential dichotomy" between state action and private conduct); Burton v. Wilmington Parking Auth., 365 U.S. 715, 722 (1961) ("private conduct abridging individual rights does no violence to the Equal Protection Clause"), the right of party members to equal representation on party central committees depends, as a preliminary matter, upon the existence of state involvement in apportionment of central committee members. State laws that establish and enforce apportionment of central committee members are state action of the most unequivocal sort. L. TRIBE, American Constitutional LAw 1147 (1978); Kester, Constitutional Restrictions on Political Parties, 60 VA. L. REv. 735, 769-64 (1974).

When state law delegates the apportionment decision to the political parties, see, e.g., Del. Code AnN., tit. 15, § 101(13), (21) (1974 \& Supp. 1977); GA. Code ANN. § 34-902 (1970), central committee malapportionment cannot be considered the product of state action, notwithstanding the integral relation of central committee activities to the electoral process, see p. 173-77 infra. The integral relation doctrine derives from United States v. Classic, 313 U.S. 299,314 (1941), which upheld a federal indictment for a false counting of primary election ballots on the ground that primarics are an "integral part" of congressional elections. Classic involved not the state action issue but the extent of the power of Congress to supervise congressional elections. Subsequent use of the integral relation doctrine by the Court has served only to apply constitutional restraints to procedures that could be independently established as state action. In Gray $v$. Sanders, 372 U.S. 368 (1963), which applied the "one person, one vote" principle to primary elections, the Court attributed state action to party primarics because state law had established the primary election. Id. at 374-75 ("state regulation of this preliminary phase of the election process makes it state action"). But the Court explicitly declined to rule on whether equal protection standards extend to nominating conventions apportioned by party rules. Id. at 378 n.10. In Moore v. Ogilvie, 394 U.S. 814 (1969), moreover, the Court found that use of nominating petitions by independents was an "integral part" of the state electoral process and thus subject to equal protection requirements, because state law had imposed the integral procedure.

In the Texas IVhite Primary Cases, the Court applicd constitutional restraints to political parties in the absence of explicit state involvement. See Terry v. Adams, 345 U.S. 461, 469 (1953) (Black, J., announcing judgment of Court, joined by Douglas, J., and Burton, J.) (state violated Fifteenth Amendment by allowing private political club that was "an integral part, indeed the only effective part" of county electoral process to deny membership to blacks); Smith v. Allwright, 321 U.S. 649, 664 (1944) (Fifteenth Amendment is violated when state "endorses, adopts and enforces" political party decision to bar blacks from voting in party's state-run primary). It is doubtful that the Court would find state action in these matters today in a case that did not involve Fifteenth Amendment claims of racial discrimination. The Court in O'Brien v. Brown, 409 U.S. 1 (1972), voided an injunction issued against the 1972 Democratic National Convention Credentials Committec unseating of two contested delegations, noting the "absence of authority" for the lower court's ruling that the convention acted as the state. Id. at 4 . Distinguishing Terry 
Fourteenth Amendment requires states to treat party members equally in designing aspects of the electoral process that affect the choice of candidates presented to the general electorate. Because of the central committee's role in determining the range of party candidates who compete in general elections, central committees are related more integrally to the state's system of elections than courts have recognized. Central committees, when apportioned by state law, should therefore represent party members equally. After considering alternative methods of allocating central committee representation, the Note concludes that use of multimember districts for the selection of central committees best avoids the shortcomings of weighted voting and districts drawn to include the same number of party members and would provide for equal central committee representation of the party faithful.

\section{The Equal Protection Clause and the Electoral Process}

In cases challenging other inequalities in the electoral process, courts have recognized that citizens have a fundamental interest in "full and effective participation" in government. ${ }^{18}$ The central aspect of the right to full and effective participation is the requirement that states give citizens an "equally effective voice" in general elections. ${ }^{10}$ This consti-

v. Adams, 345 U.S. 461 (1953), and Smith v. Allwright, 321 U.S. 649 (1944), the Court observed that "[t]his is not a case in which claims are made that injury arises from invidious discrimination based on race in a primary contest within a single State." 409 U.S. at 4 n.1. The Court in Cousins v. Wigoda, 419 U.S. 477 (1975), cited the Texas White Primary Cases as relevant to the question (reserved in Cousins) of whether delegate selection decisions of a national party are state action. $I d$. at 483 n.4. Yet, the other cases cited in the Cousins footnote had reached a variety of conclusions on the state action issue. Id.

In Jackson v. Metropolitan Edison Co., 419 U.S. 345 (1974), and Moose Lodge No. 107 v. Irvis, 407 U.S. 163 (1972), the Court limited narrowly the circumstances in which private activities can be considered state action. The Jackson and Moose Lodge decisions require that even a private activity regulated by a state not be considered state action unless the initiative for the private activity (e.g., apportionment of central committce members) comes from the state. Thus when political parties make the apportionment decision themselves, constitutional restraints do not apply. Cf. Ripon Soc'y v. National Republican Party, 525 F.2d 567, 585 (D.C. Cir. 1975), cert. denied, 425 U.S. 933 (1976) (First Amendment protects national political party's choice of convention delegate apportionment plan). See generally Kester, supra, at 737-60; Developments in the Law-Elections, supra note 11, at $1155 \cdot 63$.

18. E.g., Reynolds v. Sims, 377 U.S. 533, 565 (1964).

19. Id.; see Dunn v. Blumstein, 405 U.S. 330,336 (1972) (citizens have "constitutionally protected right to participate in elections on an equal basis with other citizens in the jurisliction"). Compare Whitc v. Regester, 412 U.S. 755, 766-69 (1973) (invalidating multimember district system of state legislature when plaintiffs produced evidence that "the political processes leading to nomination and election were not equally open to participation" by blacks and Mexican Americans) with Whitcomb v. Chavis, 403 U.S. 124, 149-53 (1971) (upholding multimember district plan under which few poor blacks had been elected to the state lrgislature but under which poor blacks had "equal opportunity to participate in and influence the selection of candidates and legislators"). 
tutional requirement is justified because government is conducted by elected representatives. ${ }^{20}$ The courts thus have recognized that full and effective participation in government entails an equal vote at general elections.

To preserve each citizen's right to an equally effective voice in general elections, courts have extended strict equal protection scrutiny ${ }^{21}$ to aspects of the electoral process that are an "integral part" of general elections. ${ }^{22}$ In Gray v. Sanders"s the Supreme Court applied the "one person, one vote" rule to state-conducted primary elections. ${ }^{24}$ Some lower courts subsequently held that the equal protection clause applies to party nominating conventions to the extent that state involvement and an integral relation to the general election could be found. ${ }^{25}$ The integral part doctrine also has been used to invalidate

20. See, e.g., Hadley v. Junior College Dist., 397 U.S. 50, 53-54 (1970) (applying equal vote doctrine to election of junior college district trustees); Arery v. Midland County, 390 U.S. 474, 484-85 (1968) (applying equal vote doctrine to election of county commissioner's court). But cf. Salyer Land Co. v. Tulare Lake Basin Water Storage Dist., 410 U.S. 719, 728 (1973) (states may limit franchise in "special limited purpose" elections); Gordon v. Lance, 403 U.S. 1, 7 (1971) (upholding requirement that proposals for public bonded indebtedness receive approval of $60 \%$ of votes cast); Wells v. Edwards, 347 F. Supp. 453, 454-55 (M.D. La. 1972), aff'd mem., 409 U.S. 1095 (1973) ("one person, one vote" rule does not apply to selection of government officials such as judges, who make decisions indcpendently rather than on behalf of constituency).

21. Courts invoke strict equal protection scrutiny when state action abridges a fundamental interest of a class of citizens or creates a suspect classification. Only a showing that such discriminatory state action is necessary to promote a compelling state interest will preserve the state classification from judicial invalidation. E.g., Storer v. Brown, 415 U.S. 724, 729 (1974); see G. Gunther, Cases and M.ITERIals on Constitution.il Liw 658-60 (9th ed. 1975).

22. See United States v. Classic, 313 U.S. 299, 314 (1941) (primaries are "integral part" of general elections).

23. 372 U.S. 368 (1963).

24. At issue in Gray was the Georgia county-unit system of primary elections that gave added weight to primary votes cast in sparsely populated counties. Id. at 370-72.

25. E.g., Georgia v. National Democratic Party, 447 F.2d 1271, 1274-78 (D.C. Cir.), cert. denied, 404 U.S. 858 (1971) (Democratic National Convention); Maxey v. Washington State Democratic Comm., 319 F. Supp. 673, 679.82 (W.D. Wash. 1970) (selection of state delegates to Democratic National Convention). In Gray the Supreme Court explicitly declined to rule on the applicability of the "one person, one vote" principle to party nominating conventions. 372 U.S. at 378 n.10. Courts in subsequent cases have refused to find state action in nominating conventions and thus have withheld Fourteenth Amendment relief. See, e.g., O'Brien v. Brown, 409 U.S. 1, 5 (1972) (roicing "grave doubts" about lower court's attribution of state action to 1972 Democratic National Convention Credentials Committee). In Ripon Soc'y v. National Republican Party, 525 F.2d 567 (D.C. Cir. 1975), cert. denied, 424 U.S. 933 (1976), the court rejected a challenge to the apportionment of delegates to the 1976 Republican National Convention, ruling that cven if nominating conventions did constitute state action, the equal protection clause would not requirc parties to use a one-party-member-one-rote basis for apportionment of national convention delegates for two reasons: (1) the First Amendment protects the party's choice of the delegate apportionment plan the party thought most effective, id. at 588, and (2) party use of an apportionment formula based on the Electoral College was rational, for the 
inequalities in state ballot-access laws that discriminate among supporters of independent candidates and of new political parties. ${ }^{26}$ As the Supreme Court has emphasized, "[a]1l procedures used by a State as an integral part" of the electoral process now must meet constitutional standards of equality. ${ }^{27}$

The integral part cases evince a common theme. Equality in general elections is jeopardized if states give citizens or party members disparate opportunities to determine the candidates for whom the general electorate may vote. Denial of an equal opportunity to participate in the candidate selection or ballot-access stage, for example, imperils the right of each citizen to an equally effective vote in general elections, because the nomination procedures ${ }^{28}$ and the requirements that an

party's success in presidential elections depended on winning a majority of Electoral College votes, id. at 586-89.

The court's misgivings in Ripon Society about applying equal protection standards to party decisions on the apportionment of nominating conventions do not apply to state laws that apportion members of party central committees. The First Amendment poses no barrier to judicial invocation of constitutional restraints when a state law rather than a private action is at issue. Moreover, the court's Electoral College reasoning is not relevant to apportionment of state and county central committees, for the elections that state and county central committees seek to win are decided by the popular vote, to which the judiciary has applied equal protection principles. See pp. 171-72 supra.

26. See, e.g., Moore v. Ogilvie, 394 U.S. 814, 818-19 (1969) (invalidating.statute that required independent candidates and new political parties seeking ballot position to collect 25,000 signatures, including signatures of 200 registered voters from at least 50 counties, where $93.4 \%$ of state's population resided in 49 most populous counties); Socialist Workers Party v. Hare, 304 F. Supp. 534, 595-36 (E.D. Mich. 1969) (invalidating ballot access law requiring candidates of new parties to secure 100 signatures from 10 counties, and not more than $35 \%$ of total signatures from one county). But cf. Udall $\mathbf{v}$. Bowen, 419 F. Supp. 746 (S.D. Ind. 1976) (upholding requirement of 500 signatures from each of 11 congressional districts); Zautra v. Miller, 348 F. Supp. 847 (D. Utah 1972) (upholding requirement of 10 signatures from each of 10 counties for party to appear on ballot); Moritt r. Governor of New York, 42 N.Y.2d 347, 366 N.E.2d 1285, 397 N.Y.S.2d 929 (1977), appeal dismissed mem., 434 U.S. 1029 (1978) (upholding law requiring statewide candidates to obtain 20,000 signatures, including 100 from each of one-half of state's congressional districts). In both Udall and Zautra the courts found that a discriminatory petition requirement was not as burdensome as the one struck down in Moore. Udall v. Bowen, 419 F. Supp. 746, $748-49$ (S.D. Ind. 1976); Zautra v. Miller, 348 F. Supp. 847, 849-50 (D. Utah 1972). But since the Supreme Court in Moore made no distinction for degree of burden, it appears that the Udall and Zautra courts misinterpreted the Moore doctrinc. See L. TRIBE, supra note 17, at 781 n.22; Developments in the Law-Elections, supra note 11 , at $1149-51$.

27. Moore v. Ogilvie, 394 U.S. 814, 818 (1969).

28. See, e.g., Newberry v. United States, 256 U.S. 232, 286 (1921) (Pitney, J., concurring in part) ("As a practical matter, the ultimate choice of the mass of voters is predetermince when the nominations have been made"); Gcorgia v. National Democratic Party, 447 F.2d 1271, 1276 (D.C. Cir.), cert. denied, 404 U.S. 858 (1971) (major partics' presidential nominating conventions are "integrally related" to general election because "electorate's choice in the general election is effectively restricted to the nominces of the two parties"); cf. Unitcd States v. Classic, 313 U.S. 299, 314 (1941) (primary is "integral" to general election because primary is "only stage of the election procedure when [party members'] choice is of significance"). 
independent candidate must meet to be listed on the general election ballot $^{29}$ filter out candidates who otherwise would be available for the electorate's consideration. ${ }^{30}$ Accordingly, courts have invalidated inequalities in preliminary phases of the electoral process that affect the range of candidates who compete in the general election. ${ }^{31}$

\section{The Integral Relation of Party Central Committees to the Electoral Process}

In past cases involving challenges to central committee malapportionment, courts generally have agreed that the equal protection clause requires central committees to represent party members equally when performing activities that are an integral part of the electoral process. Yet the courts have taken too narrow a view of the actual impact that central committee activities have on general elections.

The Second Circuit's decision in Seergy v. Kings County Republican County Committee ${ }^{32}$ is typical of the stringent view courts have taken of the integral relation between central committees and the general election. In Seergy the court ruled that administration of "internal party affairs" constitutes the bulk of a central committee's business. According to the court, such internal affairs bear "no direct relation to the electoral process," but rather are private in nature and thus beyond the scope of constitutional scrutiny..$^{* 3}$ Only when a central committee nominates candidates to fill vacancies on the party ticket or performs a limited number of other "public electoral functions,"34

29. Cf. Williams v. Rhodes, 393 U.S. 23, 31 (1968) (right to political association "means little if a party can be kept off the election ballot and thus denied an equal opportunity to win votes"); MacDougall v. Green, 335 U.S. 281, 288 (1948) (Douglas, J., dissenting) ("When candidates are chosen for the general election by a nominating petition, that procedure ... becomes an integral part of the electoral process.") Justice Douglas wrote the Court's majority opinion in Moore v: Ogilvie, 394 U.S. 814 (1969), which overruled MacDougall in holding that state-required ballot-access petitions are "integral" to the electoral process and thus subject to the requirements of the equal protection clause. 394 U.S. at 818.19.

30. See Storer v. Brown, 415 U.S. 724, 735 (1974); Bode r. National Democratic Party, 452 F.2d 1302, 1306 (D.C. Cir. 1971), cert. denied, 404 U.S. 1019 (1972).

31. E.g., Moore v. Ogilvie, 394 U.S. 814, 818 (1969); Georgia v. National Democratic Party, 447 F.2d 1271, 1276 (D.C. Cir.), cert. denied, 404 U.S. 858 (1971); Maxcy v. Washington State Democratic Committec, 319 F. Supp. 673, 679 (W.D. Wash. 1970).

32. 459 F.2d 308 (2d Cir. 1972).

33. Id. at 314 .

34. The Second Circuit in Seergy ruled that the state-apportioned central committec must represent party members equally when performing the "public electoral function" of granting permission for a non-party member to become a candidate for party nomination. Id. In Doty v. Montana State Democratic Cent. Comm., 333 F. Supp. 49 (D. Mont. 1971), the court held that central committee selection of delegates who play any part in selection of delegates to presidential nominating conventions also was a "public electoral function" that required equal representation of party members. $I d$. at $5 l$. 
reasoned the court, are central committee activities integrally related to the general election. ${ }^{35}$ The Second Circuit held that the equal protection clause requires equal representation of party members on the party central committee only on these rare occasions. Other courts have adopted similar reasoning. ${ }^{36}$

Central committees normally filter and restrict the range of party candidates presented to voters at the general election to a much greater extent than courts have recognized. Long before primaries and conventions take place the central committee may effectively determine the party's ultimate choice by recruiting, screening, and endorsing candidates for party nomination. ${ }^{37}$

Pursuant to law in some states and according to party rules in most other states, candidates for party nominations first apply for party endorsement to a screening committee established by the central committee..$^{38}$ After the screening panel appraises the candidates, the central committee endorses a slate that committee members believe will best carry the party standard in the general election. ${ }^{39}$ Frequently the

35. 459 F.2d at 314; see 39 BrooklyN L. REv. 992, 1004 (1973) ("[T] he court in Seergy went about as far as possible in cxtending the 'one man, one vote' principle within the confincs of previous court decisions"). The Second Circuit, however, could have gone further than it did in Seergy. The court underestimated not only the "confines" of the Supreme Court's integral relation test, see p. 172-74 supra, but also the extent to which the so-called "internal affairs" to which central committees attend are integrally related to the electoral process, see pp. 175-77 infra.

36. Although widely adopted as the standard for applying the equal protection clause to central committee apportionment, the integral relation theory has produced a variety of results in previous cases involving central committee representation. Compare Seergy v. Kings County Republican County Comm., 459 F.2d 308, 313-15 (2d Cir. 1972) and Doty v. Montana State Democratic Central Comm., 333 F. Supp. 49, 51 (D. Mont. 1971) (central committee must represent party members equally whenever committee makes extraordinary nominations or performs other public electoral functions) and Lynch v. Torquato, 343 F.2d 370, 372.74 (3d Cir. 1965) (acknowledging party members' right to equal central committee representation when committee activities are integrally related to electoral process, but holding that integral relation issue was not ripe for decision since malapportioned central committee was not preparing to perform any public electoral function) with Dahl v. Republican State Comm., 319 F. Supp. 682, 684 (TV.D. Wash. 1970) ("The election of the state committee is not an integral phase of the presidential-election process.") and Rogers v. State Comm. of Republican Party, 96 N.J. Super. 265, 271, 232 A.2d 852, 855 (Super. Ct. Law Div. 1967) (relation between central committees and electoral process not close enough to warrant equal protection relief).

37. See pp. 176.77 infra.

38. E.g., R.I. GEN. LAws \$ 17-12-4 (Supp. 1977); Resolution Adopted by the Franklin County [Ohio] Democratic Executive Committee at its meeting held on July 24, 1974 (on file with the Jale Law Journal); see R. HeckshorN, supra note 12, at 105; V.O. KEY, supra note 10 , at 381 ; F. SORAtF, supra note 2 , at 222-23.

39. A central committee sometimes declines to endorse candidates officially for strategic reasons, as when the committee may be vulnerable to charges of "bossism." On such occasions, central committecs may act covertly to accomplish the equivalent of an outright endorsement. See F. Sor.tuf, supra note 2, at 222-23. The laws of a few states forbid or discourage party organizations to endorse candidates for party nominations. See, e.g., CAL. Elfc. Code $\$ 11702$ (West 1977) (endorsement prohibited); Wis. StaT. AxN. $\$ 8.18$ (West 
central committee arranges a "harmony ticket" that designates potential opponents as candidates for separate offices and accommodates diverse interest groups in the party in order to avoid a ruinous intraparty battle for nominations. ${ }^{40}$

Central committee endorsement affords numerous advantages to favored candidates. In some states in which party nominees are selected at a primary election, candidates endorsed by the central committee receive preferred positions on the primary election ballot. ${ }^{41}$ During primary campaigns the party's cadre of ward and precinct workers promotes the committee slate through extensive door-to-door canvassing. ${ }^{42}$ Endorsed candidates often receive favorable, if not exclusive, publicity in party publications and on sample ballots distributed before the primary. ${ }^{43}$ Endorsees also have ready access to funds and computerized voter lists maintained by committee members or the party chairman. ${ }^{44}$ In states in which party candidates are nominated by a party convention, central committee endorsement will commend the favored candidates to organization loyalists among the delegates.

Central committee endorsement of one candidate places other party hopefuls for the same office at such a disadvantage that many unendorsed candidates withdraw from contention before the primary or convention occurs. ${ }^{4 \overline{5}}$ Because a substantial part of the electorate in

Supp. 1977) (party convention convenes after primary). As Professor Key has observed, however, "[u]nder these circumstances the leadership core of the party may act informally or may even create extralegal political committces that assume the function of slatcmaking and leadership in the nominating process." V.O. KEY, supra note 10, at 382 .

40. See V.O. KEY, supra note 10 , at 382 n.16.

41. E.g., R.I. GEN. LAws $\$ 17-15-8$ (1969) (name of endorsed candidate printed on primary ballot in first column at right of title of office sought and marked with asterisk); cf. Colo. Rev. STAT. \$ 1-14-209 (1973) (candidates for party nomination placed on primary ballot in order of votes received at preprimary assembly of party members). See generally Note, California Ballot Position Statutes: An Unconstitutional Advantage to Incumbents, 45 S. Cal. L. Rev. 365 (1972).

42. See A. RanNey \& W. Kendald, supra note 10, at 226; F. Sorauf, supra note 2, at 223.

43. Telephone interview with Pat Sweet. Executive Director, Franklin County, Ohio Democratic Party (March 24, 1978) (notes on file with the Yale Law Journal).

44. Id.

45. Id.; cf. V.O. KEY, supra note 10, at 382 (uncontested nomination is often indicative of "extensive bargaining .. . within the leadership ranks to quell incipient rebellion").

Of course, groups other than party central committees also may filter and restrict the range of candidates presented to the general electorate. Endorsement by the governing committee of a farmers' cooperative organization, for example, may discourage other candidates in some areas and effectively guarantee nomination of the farmers' favorite. let the integral relation of such a committec to general elections would not compel the state to provide for equal representation of organization members even if state law apportioned membership on the gorerning committee of the farmers' organization. See note 17 supra. Courts developed the integral relation doctrine to protect the rights of citizens to an equally effective voice in general elections, see pp. 171-72 supra, and thus have applicd 
primaries is composed of party loyalists, ${ }^{46}$ challengers rarely run successfully against endorsed candidates in primary campaigns for party nominations. ${ }^{47}$ Indeed, especially in races for less visible offices, party members regularly ratify the central committee slate. ${ }^{48}$

Of course, the power that central committees wield over party nominations is not always decisive. Contestants in pitched battles for major offices sometimes develop personal campaign organizations that rival the power of the central committee. ${ }^{40}$ In such cases, central committee endorsement may play a lesser role in determining the outcome. Moreover, the equal vote that party members have in primaries and often have at nominating conventions may, to some extent, mitigate inequalities in central committee representation. Yet the integral relation of central committees to general elections is not significantly diminished by the occasional inability of central committees to exert total control over party nominations. ${ }^{50}$

this analysis only to organizations within the electoral process in which all citizens have a right to membership. See pp. 172-73 \& note 25 supwa. Private groups such as farmers' cooperatives generally are neither open to the public nor engaged primarily in political activities in the electoral process. Because the public does not have a right to join private groups such as farmers' cooperatives, which are essentially non-political in nature, it would be inappropriate to apply constitutional restraints, heretofore applied only to the electoral process and political partics, to such groups.

46. F. Sorauf, supra note 2, at 228-29.

47. Ranney, Candidate Selection and Party Cohesion in Britain and the United States, in Approaches to the Study of Party Organization 146 (W. Crotty ed. 1968). As Professor Sorauf explains, "Parties count on the fact that a substantial part of [the primary electorate] is likely to be loyalists who respond to the cues of party leaders or endorsements. So, strong party organizations able to mobilize voters, money, and manpower are still the most effective determiners of primary outcomes." F. Sokauf, supra note 2, at 231. When asked what happens in primaries to challengers of central committee endorsees, the chairman of one powerful county central committee, who preferred to remain anonymous, exclaimed: "We kick the hell out of them, that's what we do. That's what you call practical politics." Telephone interview (May 2, 1977) (notes on file with Vale Law Journal); see R. Huckshorn, supra note 12, at 105.06 (Illinois Democratic Central Committee "has seldom been troubled by serious primary opposition").

48. See Brief of Amicus Curiac at Appendix A, Fahcy v. Darigan, 405 F. Supp. 1386 (D.R.I. 1975) (on file with Yale Law Journal) (citing experience in Providence, R.I.). The impact of a central committee's endorsement was also illustrated by the results of the September 1977 New Haven, Connecticut Democratic primary, in which party members chose nominees for Board of Aldermen and mayor. The New Haven Town Democratic Committee endorsed eleven candidates for the Board plus a candidate for mayor; party members nominated ten of the endorsees for the Board of Aldermen and ratified the Town Committec's candidate for the mayoral nomination. New Haven Journal-Courier, September 16, 1977, at 1 , col. 6, \& 17, col. 1 .

49. In the 1970 Democratic primary, for example, maverick Elizabeth Holtzman asscmbled a vast volunteer corps to defeat longtime Brooklyn Congressman and central committec endorsec Emanuel Celler for the Democratic congressiomal nomination. M. BARone, G. UJufesa \& D. MItThews, supra note 8, at 584-85.

50. Even primaries and conventions, which courts have deemed to be integrally related to the clectoral process, do not finally determine which candidates may compete in the general election, since independent and write-in candidates may still obtain access to the 
A few central committee functions may have little or no direct impact on a party's candidate selection process. For example, a central committee's decision to relocate the party headquarters would not directly affect the party's choice of candidates for the general election. To allow a malapportioned central committee to make such a decision would not directly impair the party members' right to participate equally in the general election.

Nevertheless, legislatures or courts could not attempt to isolate the many central committee activities that are integrally related to general elections and to provide for equal representation of party members only on such occasions without seriously threatening the equality that the Fourteenth Amendment seeks to assure. In any representative body, each representative maximizes his effectiveness and the welfare of his constituents through negotiation and compromise with other representatives. ${ }^{51}$ Selective application of the equal protection clause may thwart the effectiveness of provisions for equal representation of party members when central committees make decisions that are integrally related to general elections. Moreover, any partial remedy would create serious problems of interpretation and enforcement and might allow opportunities for complete evasion by a majority of committee members who represent a minority of party members. ${ }^{52}$ Instead, the constitutional standard of an equally effective voice for party members should apply to the full range of central committee activities.

general election ballot notwithstanding the major parties' nominations. See Developments in the Law-Elections, supra note 11, at 1121-30. To be sure, the chances for election of independent and write-in candidates are even more remote than the prospects of unendorsed candidates for party nominations. See id. at 1123. Yet, as the Supreme Court made clear in United States v. Classic, 313 U.S. 299 (1941), the integral connection between primaries and gencral elections does not depend on whether the primary "invariably, sometimes or never determines the ultimate choice" of public officials. $I d$. at 318 . Thus if central committec endorsements sometimes are not decisive, that fact does not undermine the integral relationship between central committee activities and general elcctions. The Supreme Court of Rhode Island therefore improperly rejected the argument in Gallant v. LaFrance, 101 R.I. 299, 305, 222 A.2d 567, 570 (1966), that central committce cndorsement of candidates is an integral part of the electoral process. The advantage that central committce endorscment provides to endorsed candidates is of such consequence that inequality in the cndorsement process can lead directly to inequality at the primary or convention.

51. See D. 'Truman, The Governmental Process 368 (1971) ("The very essence of the legislative process is the willingness to accept trading as a means.")

52. Legislative or judicial provision for equal representation of party members only when central committees make decisions that are integral to the general clection could lead to considerable litigation over which procedures and votes are integral. More. over, a majority of committee members representing a minority of party members might avoid a limited equal representation order by placing themselves on an executive committee to which they could delegate power to screen and endorse candidates and to select the party chairman. See State ex rel. Pfeifer v. Stoncking, 80 Ohio App. 70, 76, 74 N.E.2d 759,763 (1946) (in absence of statute, central committe may athorize complete delegation of its powcr to executive committee). 


\section{Applying the Equal Protection Clause to Apportionment of Central Committee Members}

Because a broad range of central committee activities are integrally related to the electoral process, states that apportion central committee members should ensure that the committee members represent party members equally ${ }^{53}$ Party members are the only proper constituency of a central committee..$^{54}$ State law generally restricts participation in elections for the central committee to party members. ${ }^{55}$ Such restriction reflects a proper appreciation of the role of party officials. Although the central committee endorses candidates to be offered to the electorate at the general election, the committee does so from the perspective of advancing partisan interests. In apportioning central committee members, it is thus party members for whom states must provide equal representation.

State schemes that apportion equal numbers of committee members to districts that contain unequal numbers of party members serve several purposes, including the promotion of statewide political parties $^{56}$ and the protection of regional minorities within parties. ${ }^{57}$ Courts

53. The Supreme Court requires states "as nearly as practicable" to achicve precise mathematical equality in apportionment of congressional districts. E.g., Kirkpatrick v. Preisler, 394 U.S. 526, 530.31 (1969); Wesberry v. Sanders, 376 U.S. 1, 7-8 (1964). Yet in Reynolds v. Sims, 377 U.S. 533, 577-81 (1964), the Court recognized that, although population is the sole criterion to be considered in drawing congressional districts, states constitutionally may seek to accord political subdivisions some degree of representation in state legislatures. The maximum deviation from strict equality that the Court thus far has approved in apportionment of state legislative districts was contained in an apportionment plan in which no legislator represented $16.4 \%$ more or less constituents than any other legislator. See Mahan v. Howell, 410 U.S. 315 (1973); cf. Abate v. Mundt, 403 U.S. 182, 185 (1971) ("deviations from population cquality must be justificd by legitimate state considerations"). To justify deviations from strict equality in apportionment of central committee representation, states should show that the state legislative standard is the appropriate one by which to judge central commitee representation and that such deviations resulted from the state's desire to maintain the integrity of political boundaries that form the basis for party opcrations. See p. 182 infra.

54. Cf. Georgia : National Democratic Party, 447 F.2d 1271, 1279 (D.C. Cir.), cert. deniel, 404 L.S. 858 (1971) (party' convention delegate's "constituency . . . is composed only of the voters ... who are of like political persuasion"). But cf. Ripon Soc'y v. National Republican Party, 525 F.2d 567, 585 (D.C. Cir. 1975), cert. denied, 424 U.S. 933 (1976) (dictum) (political party is "more than a forum for all its adherents' views").

55. See, e.g., Ariz. Rev. Stat. ANN. \$ 16.231 (West 1975); Ohio Rev. Code ANN. \$ 3517.02 (Page 1972). Party members choose their central committec representatives at the primary election, e.g., TEx.s. Covr ANN. \$ 2-130-4 (Supp. 1977), or party convention, e.g., Neb. Rev. StAT. \$ $32-556$ (1974). In some cases, committee members at higher levels of party organization sit $\mathrm{ex}$ officio by virtue of elcction to central committees at a lower level of the party organization, e.g., CoLo. Rev. STAT. $\$ 1-14-108(2)$ (a) (Supp. 1976).

50. See Scergy v. Kings County Republican County Comm., 459 F.2d 308, 313-14 (2d Cir. 1972) (dictum). The state of Illinois made the same point in Communist Party v. State Bd. of Elections, 518 F.2d 517, $521-22$ (7th Cir.), cert. denied, 423 U.S. 986 (1975).

57. Cf. Lucas v. Colorado Gen. Assembly, 377 U.S. 713, 751 (1964) (Stewart, J., dissenting) (deriations from population equality in apportionment of state legislatures may 
have been nearly unanimous, however, in holding that states may not encourage development of statewide political parties through laws that discriminate among party members. 58 In addition, courts have consistently struck down statutes that safeguard the interests of various intraparty groups by giving some party members a greater opportunity than others to affect the party's candidate selection process. ${ }^{58} \mathrm{~A}$ state's purported goals in malapportioning party governance structures therefore are not sufficiently compelling to prevail over the party members' fundamental interest in equal representation on party central committees. Absent a compelling state interest in thus abridging the fundamental right of party members to an equally effective voice in general elections, courts should hold unconstitutional a state's action in malapportioning central committee representation.

The remedy for unconstitutional central committee apportionment should come from legislatures in the first instance. Originally, states adopted the central committee method of party governance to ensure that leaders of political parties that compete for control of government would be accountable to party members. ${ }^{60}$ Unless all party members have an equal voice on the central committee, however, party leaders may be more accountable to some party members than to others. In order to ensure democratic party governance and to protect the party members' right to equal central committee representation, legislatures should apportion central committee members equally among party adherents. ${ }^{01}$

produce "fair, effective, and balanced representation of the regional, social, and economic interests within a State"); Bickel, The Durability of Colegrove v. Green, 72 Yar. L.J. 39, 43 (1962) (malapportionment of state legislatures may help to preserve two party system or ensure legislative representation of minority groups).

58. See note 26 supra.

59. See, e.g., Gray v. Sanders, 372 U.S. 368, 380 (1963).

60. See People v. Democratic Gen. Comm., 164 N.Y. 335, 342, 58 N.E. 124, 126 (1900) ("the scheme is to permit the voters to construct the organization from the bottom upwards, instead of permitting leaders to construct it from the top downwards"); F. Sorauf, Political Parties in the American System 46.47 (1964); Notc, Freedom of Association and the Selection of Delegates to National Political Conventions, 56 Cornelz L. REv. 148, 153-54 (1970).

61. Although the First Amendment protects the right of citizens to form political parties, e.g., Buckley v. Valco, 424 U.S. 1, 15 (1976); Williams v. Rhodes, 393 U.S. 23, $30-31$ (1968), political partics within a state are subject to state-imposed democratic governance procedures such as central committecs, e.g., Zautra v. Miller, 348 F. Supp. 847, 851 (D. Utah 1972); King v. Willis, 333 F. Supp. 670, 674-75 (D. Del. 1971); see Notc, supra note 60 , at 153-58. Indecd, states have a compelling interest in prescrving the integrity and fairness of party governance by requiring parties to govern themselves through central committes, for political parties compete for control of governments. See L. TRIBE, supra note 17, at 777 (constitutional violations occur only when required procedures become overly restrictive).

The Supreme Court's decision in Cousins v. Wigoda, 419 U.S. 477 (1975), does not hold to the contrary; it mercly prohibits states from attempting to control procedures of na- 
There are several constitutional methods of apportionment that states can use to provide for equal central committee representation of party members. ${ }^{62}$ Whatever plan a state chooses must include a standard for determining the number of party members in a district. Such a standard should look to the actual constituency of the central committee. This in turn requires an investigation of local patterns of political behavior. Although party registration figures normally would be the appropriate measure, ${ }^{63}$ statistics on votes cast in recent elections may also be useful for measuring party membership. ${ }^{64}$ In the latter

tional political parties. The Court reasoned that to allow each state to make separate rules regarding the seating of delegates at the national convention "could seriously undercut or indeed destroy the effectiveness of the National Party Convention as a concerted enterprise engaged in the vital process of choosing Presidential and Vice-Presidential candidates." Id. at 490. Cousins thus does not impose limits on a state's power to prescribe standards for the governance of state and county political partics. As Judge Pettine later noted in Fahey v. Darigan, 405 F. Supp. 1386 (D.R.I. 1975), "a different balance may be struck when state interests are pitted against purely state or local party interests." Id. at 1395; see Rotunda, Constitutional and Statutory Restrictions on Political Parties in the Wake of Cousins v. Wigoda, 53 TEx. L. REv. 935, 950-51 (1975) (emphasizing difference between state regulation of local, as opposed to extraterritorial, party activities); Developments in the Law-Elections, supra note 11, at 1210-11 (Cousins does not rule out reasonable state regulation of state parties).

62. Courts rarely have questioned that the state's interest in promoting democratic party governance through the central committee requirement includes the power to apportion committee members. Apportionment of committee members is the least drastic means by which states can cffectuate their interest in ensuring that parties are governed on a democratic basis. The Supreme Court, moreover, has countenanced statutory restrictions of matters even more fundamental to a party's existence, such as participation in party activities. See Rosario v. Rockfeller, 410 U.S. 752 (1973) (upholding New York law limiting right to vote in party primary to voters who had enrolled as party members at least eight months before primary). But cf. Kusper v. Pontikes, 414 U.S. 51 (1973) (invalidating statute that required citizens to forego participation in primary in order to change party registration).

In Fahey v. Darigan, 405 F. Supp. 1386 (D.R.I. 1975), the court struck down on First Amendment grounds a Rhode Island law that apportioned members on the Providence City Committec of each party. The Fahey case arose, however, in an unusual context. The statutory apportionment invalidated in Fahey, limited to the central committees in one city and inspired by questionable legislative motives (the law proved to be a ploy to ensconce a local party chairman by allowing the chairman to pack the statutorily enlarged committee with supporters), is readily distinguishable from bona fide state efforts to cusure representative party governance by apportioning committee members. Indeed, as the court noted, the state would have a compelling interest in remedying an existing committec malapportionment. Id. at 1396.

63. In states with a predominant political party (e.g., Louisiana, where $94 \%$ of the votels ate 1 egistered as Democrats) or in states where most voters register as members of one party but commonly split their ticket at the general election (e.g., Oklahoma, where $76^{\circ}:$ of the wters are registered Democrats but the two U.S. Senators and one of the six Congressmen are Republicans), party registration figures may not be an accurate measure of party strength. See M. B.ArovE, G. CJIfus.1 \& D. M.ırriews, supra note 8, at 330 (Louisiana); id. at 693-70-1 (Oklahoma).

64. For example, the staudard used for defining "party member" in New York is the number of votes cast for the party's guhernatorial candidate at the preceding general election. X.Y. Eı.kc. L.ww \$2-101(1) (McKinney 1977). In Doty v. Montana State Democratic 
case, care should be taken to select election figures that accurately reflect a party's true support. ${ }^{6-5}$

Instead of basing central committee representation on political subdivisions, such as wards and counties, that contain unequal numbers of party members, ${ }^{\circ 6}$ legislacures could provide for special central committee districts in which equal numbers of party members live."77 To each such district the legislature would allocate an equal number of committee members, thus ensuring that each party member will enjoy the same representation on the party central committee.

Before relying on special central committee districts, however, the legislature should consider the need to respect existing political boundaries that form the basis for party activities. Central committee members are responsible for organizing party election efforts within the precincts, wards, counties, and legislative districts that they represent. Districts in which equal numbers of party members live inevitably would cut across these boundaries. To ignore existing political lines in favor of central committee districts of equal party member population could disrupt party operations by forcing parties to undertake a massive recoordination of their election efforts.

Legislative adoption of a weighted voting system for committee members can provide for equal representation of party members within the framework of an apportionment plan based on existing. political subdivisions. ${ }^{68}$ Weighted voting attempts to compensate un-

Central Comm., 333 F. Supp. 49, 52 (D. Mont. 1971), the court ordered use of results from past central committec races as the standard for "party member." Election retums may be deficient as a standard for defining party membership. however, because party members may inadrertently forfeit future central committee repesentation by failing to rote.

65. The state of W'ashington, for example, uscs a "blanket primary" at which roters may cast their ballots for any candidate of either party for each office. WASH. RrV. CODE ANN. $\$ 29.18 .200$ (West 1965 ). It is thus doubtful that use of sote totals received by party candidates for a particular office in such a primary would provide an accurate index of party membership in each central committec districe.

66. See note 8 supra.

67. Some states have provided for partial use of central committee districts in which equal numbers of party members or citizens live. See, e.g., C.IL. Elec. Cone $\$ 8820$ (WWest 1977) (Democratic Party central committces in certain sparscly populated countics must reapportion themselses every ten years into districts containing no more than $10^{\prime \prime} \%$ deviation from equal number of registered Democrats); Mo. ANN. STit. \$ 115.607 (Vemon Supp. 1978) (in countics containing portion of citics that exceed 300,000 in population, county election authority required to divide townships into central committec subdivisions of cqual population). Conceivably, the majority party in the legislature or apportionment board might take unfair adlantage of the minority party by drawing central committec districts that seriously inconvenience the minority" party's opetations. In order to avert this possibility, states that provide for central committec districts in which equal numbers of party members live should specify that the districts are to be drawn either by each party or by a public board (e.s., a Board of Elections) on which each party has an equal number of members.

6\%. Courts have required use of weighted roting in previous cases applying equal protection standarts to extratdinary nominations and other "public clectoral functions" performed by central committes. See Secrgy v. Kings County Republican County Comm., 
derrepresented party members by adjusting the number of votes their committee members cast. Under a system of weighted voting, each committee member casts votes in proportion to the number of party members he represents. Such a remedy has certain obvious advantages: it is precise, mathematically simple, and does not require creation of complex new districts.

Despite its administrative advantages, weighted voting may perpetuate inequalities in central committee representation. ${ }^{69}$ The true voting power of a committee member is measured not by the number of votes cast but rather by the ability of each committee member's vote to affect the outcome of central committee balloting. ${ }^{70}$ Where central committees represent a heavily concentrated party membership, a committee member with a larger than average number of votes would have more to offer colleagues seeking to build a majority coalition than a committee member with fewer votes and could exert an influence over committee decisions disproportionate to the size of his weighted vote. ${ }^{71}$ Moreover, unless committee members use weighted voting to determine the procedure by which substantive issues shall be decided, committee members seeking to preserve the advantages of malapportionment may be able to evade the legislature's intent by resorting to voice votes on substantive matters. ${ }^{72}$

459 F.2d 308, 313-15 (2d Cir. 1972); Doty v. Montana State Democratic Cent. Comm., 333 F. Supp. 49, 51.52 (D. Mont. 1971).

In states that do not provide for weighted roting, party central committees might attempt to adopt such a measure to ameliorate malapportionment. But courts have been reluctant to allow committees to adopt procedures that contravene the apparent legislative intent, see p. $180 \&$ notes $58-59$ supra, of party organization statutes. See Bacon v. Schmieding, 138 Misc. 464, 246 N.Y.S. 254 (Sup. Ct. 1930); Burton v. Schmidt, 128 Misc. 270, 218 X.Y.S. 416 (Sup. Ct. 1926) (statutorily constituted central committees do not have implied power to institute organic changes such as gender-based representation); cf. Thayer v. Ganter, 174 Misc. 394, 397, 22 X.X.S.2d 6, 9 (Sup. Ct. 1940) (in absence of party authority to weight rotes or statutory provision to contrary, each committee member is to cast one votc).

69. Because weighted roting is based on current units of representation, it may also compound any discrimination against minority groups inherent in current districting schemes and may be an unsatisfactory remedy in such cases. Cf. White v. Regester, 412 U.S. 755 (1973) (insalidating use of multimember state legislative districts that minimized power of minority groups to participate in political process).

70. Banzhaf, Weighted Toting Doesn't Work: A Mathematical Analysis, 19 Rutgers $\mathrm{L}$. REv. 317, 318 (1965).

71. Id. at $324-25$. In an cxtreme case, the representative of a district in which the majority of party members live could exercise virtual dictatorial power. Banzhaf illustrates this point by posing the possibility of a representative body consisting of one representative each from five districts, of which four districts contain 10,000 constituents cach, while the remaining district contains 50,000 constituents. Id. If all measures required a mijority wote (45,001 weighted rotes) to pass, weighted voting according to the number of corstituents represented would allow the representative with 50,000 weighted rotes to pass meastures single-hindedly and to veto any measure at will. Id.

72. In adelition, wo the extent that subcommittees affect central committec decisions, use of weighted roting for balloting by the full central committec will only partially 
A better solution to the problem of allocating central committee representation equally among party members would be the use of multimember districts for central committees. Each existing unit of representation-precinct, ward, county, or legislative district-would be allocated a number of committee members proportionate to the number of party members in the unit. ${ }^{73}$ If a central committee's size would become unwieldy through use of numerous multimember districts, the units of representation to which central committee members are allocated should be combined. ${ }^{74}$ Use of multimember districts would avoid the pitfalls of both weighted voting and districts drawn to include equal numbers of party members and ensure that central committees represent party members equally. ${ }^{\mathrm{T}}$

alleviate underrepresentation. Cf. League of Neb. Municipalities r. Marsh, 209 F. Supp. 189, 195 (D. Neb. 1962) (weighted voting creates difficulties in determining committee appointments).

73. For example, in a state with nine counties, containing $100,200,300,400,500,600$, 700,800 , and 900 party members respectively, the legislature using a multimember district central committee apportionment plan could allocate one committee member per 100 party members to each county in composing a party's state central committee.

74. In the example given in note 73 , supra, the state central committee would consist of 45 members. Should that size seem unwieldy, the legislature could join counties containing party member populations as listed in the following fashion (assuming contiguity): $(100,800),(200,700),(300,600),(400,500),(900)$, and allocate one committec member to each group of counties for every 450 party members therein. The state central committee then would consist of ten members.

75. The Supreme Court has repeatedly given its blessing to use of multimember districts as a cure for malapportionment. See, e.g., Whitcomb v. Chavis, 403 U.S. 124 (1971): Fortson v: Dorses, 379 U.S. 133 (1965). The Court, however, has invalidated use of multi. member districts that minimize the power of minority groups to participate in the political process. White $r$. Regester, 412 U.S. 755 (1973); see note 19 supra. Because multimember central committee districts would be based on existing units of representation, use of such a central committe apportionment plan may magnify any discrimination inherent in current districting schemes. If such discrimination effectively denies minority group, power to participate in the electoral process, single-member clistricts would be the most advisable way to remed central committee malapportionment. Cf. note 69 sufra (compounding effect of weighted roting on discrimination inherent in current districting plans.

One commentator has suggested that nultimember districts may perpetuate incqualities in representation. Banzhaf, Multi-member Electoral Districts-Do They J'iolate the "One Man, One Tole" Principle, 75 Yale L.J. 1309 (1966). Like weighted roting, Banzhaf asset ts, the multimember district system may permit representatives from a inultimember district to exercise proportionately greater power than representatices from single-member districh. as long as the representatives from multimember districts rote as a bloc. But there is little reason to believe that representatives from multimember districts would vote as a bloc. As with the two U.S. Senators from each state whose votes ate often split, repre. sentatives of a multimember district are likely to be influeneed by mique factors in their bachgrounds and relations with constituents. Moreover, the Supreme Court hals cxpressed strong doubts concerning the validity of Banzhaf's theory in actual practice. Sec Whitcomb v. Chavis, 403 L.S. 124, 144-47, 145 $n .23$ (1971); ill. at 168-70 (Harlan. J.).

Bandhaf also contends that allocation of representation in direct poportion to population overcompensates constituents of multimember districts for their decreased ability $t 0$ affect the selection of representatives. Banehaf, supha, at 1319-24. Acconding to Bandiaf. the number of times that a roter can affect the outcome of an election for his representa. tive decrease's as the inserse of the spuare root of the district's poyulation rather than in 
Because of the fundamental constitutional rights at stake, courts should not permit legislatures to apportion central committees in a manner that provides for unequal representation of party members. When presented with a challenge to a state law that malapportions central committee representation, courts should prohibit further enforcement of the malapportionment provisions. By invalidating state laws that malapportion central committees, courts will pave the way for future reform of central committee representation either by party members or by the legislature.

\section{Conclusion}

Legislatures and courts no longer should countenance the conspicuous exemption of state-apportioned central committees from equal protection standards. The equal protection clause requires states to treat party members equally in designing aspects of the electoral process that affect the choice of candidates presented to the general electorate. Because central committees filter and restrict the range of party candidates who compete in general elections, central committees are integrally related to the state's system of elections to a much greater extent than courts previously have recognized. Central committees thus should represent party members equally when apportioned by state law. Statutory denial of equal central committee representation can lead to denial of equality not only in general elections but ultimately in the government itself.

proportion to the district's population. Id. Yet multimember central committee districts are a means to the end of providing each party member an equal ability to participate in the selection of party candidates for the general election. In the central committee context, the party member's ability to participate in candidate selection depends not on his power to affect the outcome of elections for central committee members within his district but rather on representation of the party member on the party central committee. 